seven courses, all other departments had four or fewer women and politics courses offered on a regular basis. Susan Carroll accepted the award on behalf of Rutgers University, and WCPS recognized the department chair,

Richard W. Wilson.

New York University was honored by the Caucus for having the highest percentage of female Ph.D. students, some 51\% in 1993-94. Michigan was the runner-up with 43\%; both The University of Massachusetts at Amherst and Yale reported $42 \%$. Sophia Anninos, a graduate student in the department, accepted the award on behalf of New York University, and for Christine Harrington, who at the time was being honored by the APSA Organized Section on Law and Courts with the American Judicature Society Award.

Caucus members will be examining survey results in the coming months and will present their findings in future issues of $P S$.

\section{Contributions To Ensure the Continuation of the Victoria Schuck Award}

The Victoria Schuck Award was established in 1988 to recognize an outstanding book on women and politics. The APSA Council established this award as a $\$ 500$ prize. Recipients of this award from 1988 through 1993 are:

1988: Rebecca E. Klatch, Women of the New Right

Jane Mansbridge, Why We Lost the ERA

1989: Zillah Eisenstein, The Female Body and the Law

Carol Pateman, The Sexual Contract

1990: Susan Moller Okin, Justice, Gender and Family

Judith Steihm, Arms and the Enlisted Woman

1991: Jane Sherron DeHart and Donald G. Matthews, Sex, Gender and the Politics of the ERA Iris M. Young, Justice and the Politics of Difference
1992: Nancy Caraway, Segregated Sisterhood: Racism and the Politics of American Feminism Anne Phillips, Engendering Democracy

1993: Virginia Sapiro, A Vindication of Political Virtue: The Political Theory of Mary Wollstonecraft

1994: Cynthia R. Daniels, At Women's Expense: State Power and the Politics of Fetal Rights

The endowment for this award, generously contributed by Victoria Schuck, was underfunded accord-

ing to newer guidelines established by the Council. The APSA Council requires an endowment of $\$ 12,500$ for an annual prize of $\$ 500$. At the end of 1993, the fund for the Schuck Award had only one-third of this amount. Fund-raising efforts this year, led co-equally by Jennifer Hochschild, president of the Women's Caucus in Political Science, 1993-94, Marian Palley, chair, Committee on the Status of Women in the Profession, 1991-94, and Christine Di Stefano, president, Women and Politics Organized Section, 1993-94, included appeals for contributions in a letter from all three officers to members of the Organized Section and essays in the WCPS Quarterly by Cynthia Duquette and in the Women and Politics Organized Section newsletter by Christine Di Stefano.

The response to the appeals has been excellent. At the time this issue of $P S$ went to press, contributions had been received from the following people:

Harriet B. Applewhite James C. Foster Judith Baer

Walter E. Beach

Karen Beckwith

Diane D. Blair

Janet K. Boles

Susan C. Bourque

Lisa Brandes

Barbara Burrell

Susan Carroll

Beverly B. Cook

M. Margaret Conway

Christine Di Stefano

Georgia Duerst-Lahti

Kathy E. Ferguson

Mary Ellen Fischer

Dennis Fischman

Janet A. Flammang

Jane Flax
Jill Norgren

Susan Moller Okin

Carole Pateman

Susan J. Pharr

Shane Phelan

Barbara A. Presnall

Doris Marie Provine

Fauneil Joyce Rinn

Phyllis Farley Rippey

Marie Barovic

Rosenberg

Catherine E. Rudder

Eve N. Sandberg

Virginia Sapiro

Mary L. Shanley

Roberta Sigel

Barbara L. Sinclair

These contributions have raised the endowment to a level required for an award given semi-annually. The continuation of the award is ensured for now while contributions are still being sought to meet the Council requirement. Victoria Schuck's words when this award was initiated now also express APSA's, as well as her gratitude, for these contributions:

... I have been elated at the warm response and genuine support of the idea [for the award] and the delightful spontaneous suggestion that others might want to contribute small sums to enhance the endow-

ment. ...

\section{Travel Grants for International Scholars Attending the Annual Meeting}

Fifty international scholars received travel grants to attend the 1994 annual meeting in New York City. International graduate students attending American universities were selected competitively and received travel money made available by the Huang Hsing Foundation, The Asia Foundation, and the APSA Council. Senior scholars who had been invited to participate at the Annual Meeting were also awarded travel funds set aside by the APSA Council. Still other senior scholars participating or attending the meeting were awarded travel grants through the United States Information Agency. A list of international grantees, 


\section{5}

\section{RaLPh Bunche \\ SUMMER INSTITUTE \\ June 12 - July 14, 1995}

\section{Hosted by \\ Spelman College, Emory University, Morehouse College, Georgia State University, and Clark Atlanta University}

The Ralph Bunche Summer Institute invites applications from African American students between their junior and senior years to attend the 1995 Summer Institute. Designed to introduce 20 students to the world of graduate study and encourage application to $\mathrm{Ph} . \mathrm{D}$. programs, the Institute includes two transferable credit courses, one in quantitative analysis and the other in political participation. In addition, guest lecturers and recruiters from Ph.D. programs visit with students, and the Educational Testing Service assists in preparation for taking the Graduate Record Examination.

Classes are held on the campuses of Emory University and Spelman College, and students live in the dormitories at Morehouse and Spelman Colleges. A fully equipped computer laboratory is available to the students, as are the library collections at both Emory and Georgia State University.

Students who have participated in this program over the past eight years have reported improvement in their analytical, writing, and quantitative skills. The academic environment is challenging, yet supportive. Students learn what is necessary to be successful in a graduate program and as a scholar.

Most students who attend the Ralph Bunche Summer Institute excel in their senior year and go on to graduate school, many with full graduate fellowships and teaching assistantships. A number of Institute participants have gone on to receive their masters or $\mathrm{Ph}$.D. degrees, and two have already been named assistant professors at the university level.

For more information or additional application materials please contact:

American Political Science Association

Ralph Bunche Summer Institute

1527 New Hampshire Avenue., NW

Washington, DC 20036

(202) 483-2512

or e-mail:

incem023@sivm.si.edu

Application deadline: February 1, 1995

Supported by the Coca-Cola Foundation, the Georgia State University Foundation,

the Graduate School of Emory University, and the American Political Science Association 


\section{American Political Science Association Summer Institute in Political Science for African American Students}

In cooperation with:

Spelman College, Morehouse College, Emory University, Georgia State University, and Clark Atlanta University

Deadline: February 1, 1995

NAME

\begin{tabular}{lll}
\hline Last & First & Middle
\end{tabular}

DATe OF BIRTH SEX

Current Adpress

Street

AdDRESS

Street

City

TelePhone

Permanent

Education: List ALl INSTTTUTIONS ATTENDED; CURRENT FIRST.

UNDERGRADUATE

INSTTTUTION

LOCATION

Major

GPA

Dates Attended

Present Classification (1994-1995)

(Junior, SENIOR, ETC.)

List Poldtical Science Courses taken or currently enrolled in:

(over)

This application may be reproduced as needed. 
LIST ACADEMIC HONORS AND AWARDS:

LIST EXTRACURRICULAR AND COMMUNTTY ACTIVTTIES AND AWARDS:

WHAT ARE YOUR PLANS UPON GRADUATING FROM COLLEGE?

APPLCATION MATERIALS REQUIRED:

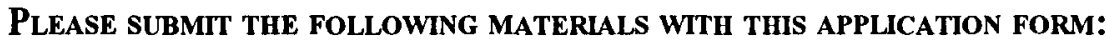

1. ACademic transcripts

2. The NAMES OF YOUR POLITICAL SCIENCE DEPARTMENT CHAIR, AND ONE OTHER PROFESSOR WHO IS FAMILIAR WITH YOUR ACADEMIC QUALIFICATIONS AND PERSONAL TRATTS WHO WILL SEND LETTERS OF RECOMMENDATION BY THE FEBRUARY 1 dEADLINE

3. A STATEMENT, NOT TO EXCEED TWO DOUBLE-SPACED TYPEWRTTEN PAGES, STATING YOUR REASONS FOR WANTING TO PARTICIPATE IN THE INSTTTUTE

Please provide the Name, Address, and telephone number of YOUR DePaRTMent Chair, AdVisor, or OTHER INSTITUTIONAL REPRESENTATIVE WHO CAN SERVE AS A CONTACT PERSON:

Please Return Completed application to:

American Political Science Association

Ralph Bunche Summer Institute

1527 New Hampshire AVenue, NW

WASHINGTON, DC 20036

Phone: (202) 483-2512

FAX: (202) 483-2657

(Please call if you have any questions) 
their countries, and their U.S. affiliations follows:

\section{The Asia Foundation}

Ryo Shimizu, Japan, University of Southern California

Ramjee Parajulee, Nepal, George Washington University

Jesse S. Giltamag, Micronesia, Northern Arizona University

OiKuan Fiona Yap, Malaysia, University of Rochester

Saadia H. Mazhar, Pakistan, Harvard University

Shin-Wha Lee, Korea, University of Maryland-College Park

Uk Heo, Korea, Texas A\&M University

Sanghwan Lee, Korea, Michigan State University

Hyunseog Yu, Korea, Northwestern University

Go Ito, Japan, University of Denver

Chyi Shen, Taiwan, University of Missouri-Columbia

Yong Deng, P.R.C., University of Arizona

Young M. Kim, Korea, SUNYBinghamton

Hahn Suhl, Korea, Pennsylvania State University

Tamoaki Nomi, Japan, University of North Carolina

Sang Hwa Chung, Korea, University of Missouri-Columbia

Qunjian Tian, P.R.C., Cornell University

You Hao, P.R.C., University of Cincinnati

Sheng Chen, Taiwan, University of New Orleans

Abdul Ghaffar Mughal, Pakistan, University of Southern California

Chun-Ming Chen, Taiwan, SUNYBuffalo

\section{APSA Council Grantees}

Gojko Vockovic, Yugoslavia, University of Southern California

Boris Sergiyev, Russia, University of California-Santa Barbara

Octavio Amorim Neto, Brazil, University of California-San Diego

Rachel K. Gibson, Great Britain, Texas A\&M University

Maria Victoria Murillo, Argentina, Harvard University
Sophie Meunier-Aitsahalia, France, Massachusetts Institute of Technology

Triantafyllos Flouris, Greece, University of South Carolina

Andrei Ponomarev, Russia, SUNYAlbany

Elisabeth Egetemeyr, Germany, SUNY-Albany

Samuel E. Quainoo, Ghana, SUNY-Binghamton

Oleg Kovalev, Russia, University of Delaware

Adnan M. Hayajneh, Jordan, University of Arizona

\section{Senior Scholar Grants-APSA \\ Council Grantees and \\ USIA Grantees}

Prem Singh, University of DurbanWestville, SA

Roger Deacon, University of Natal, SA

Sonny Venkatrathnam, University of Durban-Westville, SA

Martin Palous, Center for Theoretical Study, Czech Republic

Iqbal Ahmed Quershi, East Asia Study Centre, Pakistan

Natalia M.L.M. Morales, University of the Philippines

Rasa Aliksauskiene, University of Vilnius, Lithuania

Christopher Bailey, University of Keele, UK

Roxana Morduchowicz, Buenos Aires National University

George E. Irani, Beirut University College, Lebanon

Pervez Hoodbhoy, Quaid-i-Azam University, Pakistan

Michael Meimeth, University of Trier, Germany

Udo Bullman, Universitat Giessen, Germany

Edward Page, University of Hull, UK

Michael Cox, Queen's University of Belfast, UK

M.J.F. Goldsmith, University of Salford, UK

\section{Atlanta Ralph Bunche Summer Institute Consortium Honored}

Members of the Atlanta consortium hosting the APSA's Ralph
Bunche Summer Institute were honored at the 1994 Annual Meeting at a reception hosted by the APSA Committee on the Status of Blacks in the Profession. Committee chair Sheila Ards, University of Minnesota, acknowledged the outstanding contributions of the following individuals and institutions to the Institute's effort to encourage African American students to pursue careers in political science:

\section{Spelman College: \\ Marilyn Davis \\ Zadie Long \\ Jeanne T. Meadows \\ Lois B. Moreland}

\section{Emory University:}

Alan Abramowitz

Courtney Brown

Micheal Giles

Melanie Buckner

George Jones

Harvey Klehr

Eleanor C. Main

Andrea Simpson

Scott Taylor

Clark Atlanta University: William Boone

\section{Georgia State University: \\ C. T. Cummings \\ Naomi Lynn \\ William Thomas}

\section{Morehouse College: \\ Tobe Johnson}

The Ralph Bunche Summer Institute in Atlanta was made possible through the generous support of the Coca-Cola Foundation, the Ford Foundation, the Graduate School of Arts and Sciences of Emory University, the Georgia State University Foundation, and the U.S. Department of Education.

Another session of the Atlanta program will be held in the summer of 1995 . The 1995 program will be underwritten by the continuing generosity of the Coca-Cola Foundation, as well as by funds set aside by the APSA Council. Plans are already underway to continue the Bunche Institute in 1996 and years after; developments will be publicized in future issues of $P S$. 